\title{
Pop Culture in the Classroom: American Idol, Karl Marx, and Alexis de Tocqueville
}

Miguel Centellas, University of Mississippi

ABSTRACT This article discusses the use of pop culture in the classroom as a means to teach foundational political science authors and concepts. I focus on my experience using American Idol as a point of reference to discuss Marx and Engel's The Communist Manifesto and Tocqueville's Democracy in America in undergraduate comparative politics courses. Students are asked to construct a written argument projecting Marx or Tocqueville's perceptions of American Idol, based on their readings. My experiences demonstrate that asking students to reflect on their own contemporary experience through the prism of these two works helps them in three ways: (1) to better understand the ideas of Marx and Tocqueville, as well as their differences; (2) to develop an appreciation for the continued relevance of works in the discipline's canon; and (3) to sharpen and develop critical thinking and analytical skills.

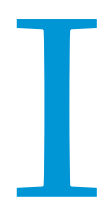

$\mathrm{n}$ this article, I discuss the use of a specific pop culture reference-American Idol-in undergraduate classes as a way to help students better engage with two classic works in the canon: The Communist Manifesto, by Karl Marx and Friedrich Engels, and Democracy in America, by Alexis de Tocqueville. This article is based on my experiences using the popular television show American Idol as a reference point for class discussions. These discussions have been effective in pushing students to grapple with and apply the complex ideas presented in their assigned readings. In addition to explaining my motivations behind such an unorthodox approach, I discuss some of the interesting arguments students that have made over the course of these arguments. More recently, I developed a writing assignment based on this theme, which strengthened and improved in-class discussions.

Marx and Tocqueville are interesting to compare for a number of reasons. The authors were contemporaries, and their works were published in close succession (Democracy in America in 1835, the Communist Manifesto in 1848). Reflecting on important social changes in their own time, each developed a theoretical model for human history and social change. Where Tocqueville saw the triumphant march of equality, Marx saw the systematic expansion of misery and exploitation. Both, however, placed the emerging middle class at the center of their analysis, presenting it as a force

Miguel Centellas is currently the Croft Visiting Assistant Professor of Political Science at the University of Mississippi, where he teaches courses in comparative politics, Latin American politics, and first-year seminars. His research focuses on the effects of institutional reforms on electoral politicsin Bolivia. He can be reached at mcentell@olemiss.edu. that eroded traditional aristocratic privileges. Each also represents a different intellectual tradition. As I often remind my students, one simple way to compare Marx and Tocqueville is to ask the question: "What is the engine of history?" For Marx, material conditions "structure" political, social, and economiclife. ForTocqueville, it is ideas that push history forward, reshaping political, social, and economic institutions. Finally, while both authors present a teleological view of history and discuss the importance of "revolutions," both weave their narrative in different ways that continue to influence debates within our discipline to this day.

Clearly, there is much that a professor can do in a classroom with Marx and Tocqueville. I have found, however, that students engage with the ideas presented by Marx and Tocqueville-ideas that remain at the root of our discipline-in rich and meaningful ways when they apply those ideas to their own contemporary experience. Just as Tocqueville's ideas about the importance of community served as inspiration for Robert Putnam's (2000) critique of America's declining social capital, or as Marx's observation about capitalism's tendency to produce ever-larger monopolies shaped Robert Reich's (2007) argument that globalization was producing a new "supercapitalism," I believe students can mine the canon for insights into their own experience. Yet because students rarely deconstruct their own social context, they often find themselves overwhelmed by the question: "What would Marx or Tocqueville think about our society today?" Instead, it is helpful to narrow that question to a specific cultural reference point. I chose American Idol, but one could use some other reference point just as well. However, American Idol works particularly well for two basic 
reasons: (1) students are more likely to be familiar with the show than with other (more niche) pop culture references, and (2) the specific format and scope of American Idol makes it particularly relevant for this particular exercise.

\section{USING POP CULTURE IN THE CLASSROOM: DILEMMAS AND OPPORTUNITIES}

A number of professors doubtless use pop culture references in the classroom, especially with an undergraduate audience. Some of us may deliberately include popular films or television programs in our curricula. ${ }^{2}$ Typically, these involve specific scenes or episodes that speak to specific relevant course themes. Scenes from The West Wing may be particularly useful to illustrate the inner workings of the U.S. presidency (Beavers 2002). Scenes from Battlestar Galactica may facilitate interesting discussions about the war on terrorism. I once acted as a teaching assistant for an undergraduate lecture course in which the professor used scenes from the television police drama Law and Order and the feature film The People vs. Larry Flynt to illustrate key concepts in constitutional law. Area studies classes are often peppered with such materials, which may be used either to illustrate important concepts or as platforms for exercises in deconstruction. Such materials not only help make otherwise dry material more fun for undergraduates, but they also help students hone critical thinking skills, integrate classroom lessons into the real world (as they understand it), and build holistic understandings of learning and exploration that are consistent with the liberal arts tradition.

The use of pop culture in the classroom is not without limitations. This approach is particularly problematic if the audience includes international students unfamiliar with some of the subtle nuances of American pop culture. An added difficulty is the increasing "balkanization" of American youth culture-if students are unfamiliar with a specific pop culture reference, they may become more confused, tune out, and become alienated from the learning experience. A Star Trek reference may mean nothing to students unfamiliar with the adventures of Captain Kirk and his crew, regardless of the show's historical impact on American multiculturalism (Bernardi 1998; Byrd 1998). A detailed explanation of a pop culture reference requires time that could instead be spent explaining the original concept. Students may then view the reference as a distracting tangent, rather than a failed analogy.

Another limitation is related to the selection of specific scenes for use in classroom discussions. A simple solution to the problem of the failed reference is to select an appropriate scene to either view in class or assign for outside viewing. This is the typical framing approach in which the teacher selects a specific chunk of material to present to students. Such a solution has its own limitations: First, there are the practical problems of selecting an appropriate scene, making it available to students, and fitting it into the course schedule (O'Connor 1987). Second, there is the ongoing problem of familiarity. Assigning scenes from The West Wing may implicitly require students to be familiar with the show's characters and previous plot lines. Third, this approach often encourages students to think of a film or television clip in the same way as any other text, generally stripped of much of its surrounding context. This understanding may be appropriate or unavoidable in specific circumstances. But a good teacher should be aware that he or she is assigning another text, and should treat it accordingly.
Finally, there is the danger that the framing itself shapes student perceptions about the subject matter. For example, The West Wing may not serve as an accurate reflection of the American presidency, but may instead foster inaccurate perceptions of the American presidency (Rollins and O'Connor 2003; Crawley 2006; Parry-Giles and Parry-Giles 2006). Students may come away from the experience believing that President Josiah Bartlet's White House is a more accurate portrayal of the inner workings of the executive branch than the descriptions they find in their textbooks.

I do not, of course, mean to dissuade teachers from using pop culture in the classroom. Some of the limitations mentioned above can be overcome if teachers are careful to select pop culture references that are widely diffused throughout society. In fact, such references offer significant advantages over the more typical framing approaches. My experience using American Idol suggests that a carefully selected pop culture reference can serve as a launch pad for rich, detailed, and innovative discussions about primary texts in the political science canon.

\section{WHY (AMERICAN) IDOL WORKS}

I have not yet met a single student who is unfamiliar with American Idol. I do not suggest that all my students watch, or even enjoy, the ratings juggernaut that is American Idol. ${ }^{3}$ Yet all of my students have a remarkable familiarity with the show's purpose, format, style, and three (now four) celebrity judges. They know that each season, the show begins with tens of thousands of contestants who wait in long lines in various cities for a chance to audition before the panel of judges (Simon Cowell, Paula Abdul, Randy Jackson, and now also Kara DioGuardi ${ }^{4}$ ). They also know that horrible auditions will be televised for viewers' amusement and that a pool of the best contestants will be formed that slowly, over several weeks, reduces to a single winner. They know, too, that in the later weeks of the show's season, the television audience members (not the judges) select who is sent home, and that viewers can vote for contestants either by phone or SMS text messaging. Even students who despise American Idol are able to deconstruct it-perhaps gleefully so-by wielding the ideas of Marx and Tocqueville as sledgehammers.

The same level of familiarity holds true for the international students that I have had in the past three years. In part, this is because licensed Idol franchises and copycats can be found in more than 40 individual countries across the globe (American Idol is itself a franchise of the original British Pop Idol), in addition to the various "regional" Idol competitions that feature contestants from several countries (e.g., Idols West Africa and the Arab world $X$ Seer al Naja). Additionally, various unlicensed copycats are found in countries around the world, even in unexpected places (e.g., Afghanistan's AfghanStar, currently in its fifth season and the recent subject of an $\mathrm{HBO}$ documentary). Needless to say, even if international students have not personally watched American Idol (which is also televised around the world by various cable and satellite networks), they are likely to have been exposed to a local version of the Idol format.

In short, American Idol works because it is so diffused across global pop culture. When I ask students to use the writings of Marx or Tocqueville to comment on American Idol, I am essentially asking them to consider how we can use the concepts, ideas, and theories of Marx and Tocqueville to understand our increasingly globalized world. In many ways, the Idol phenomenon is, like the spread of Coca-Cola, McDonald's, and Starbucks, a sign 
of our growing cultural homogeneity, a product of global neoliberal hegemony. Surely, students can find something in Tocqueville or Marx that relates to such a global process.

\section{THE CHALLENGE: MARX AND TOCQUEVILLE IN FORTY MINUTES}

Originally, my assignment consisted merely of a framing prompt announced in class before the reading assignment. This exercise has evolved into a short "reflective" essay assignment (3 to 4 pages), followed by in-class discussion. Although I found the earlier in-class discussions to be quite fruitful, I decided to push students to better prepare for discussion by asking them to formulate and express their ideas well ahead of time. This expectation has two advantages: A written assignment gives all students an equal opportunity to formulate and express their own ideas, with neither the pressures (nor the advantages) of in-class discussion. Second, the assignment gives students a chance to practice using reference citations in an argumentative essay. cal writing. The differences in interpretation actually serve a fruitful purpose by generating lively in-class debates that force students to defend their interpretations.

I am consistently impressed by how well students are able to incorporate the ideas of Marx and Tocqueville and present them in class, often fostering vigorous discussions, when asked to think about American Idol. Not only do students actively participate in class discussions, but they also show themselves able to select key passages from Marx and Tocqueville to support their positions.

\section{TOCQUEVILLE AND AMERICAN IDOL}

When I first thought of introducing American Idol into a class discussion on Tocqueville, I assumed that students would overwhelmingly argue that Tocqueville would see the show in a mostly positive light. After all, American Idol promotes the idea that anyone can become a pop star, if only he or she can connect with a television audience. Yet a number of students came to a different conclusion, pointing instead to Tocqueville's ambivalence about

\section{In short, American Idol works because it is so diffused across global pop culture. When I ask students to use the writings of Marx or Tocqueville to comment on American Idol, I am essentially asking them to consider how we can use the concepts, ideas, and theories of Marx and Tocqueville to understand our increasingly globalized world. In many ways, the Idol phenomenon is, like the spread of Coca-Cola, McDonald's, and Starbucks, a sign of our growing cultural homogeneity, a product of global neoliberal hegemony.}

It is in this format that my students encounter Tocqueville and Marx. Each author is included in a set of readings, Tocqueville on advanced democracies and Marx on communism and postcommunism; our discussions of Tocqueville and democracy precede our discussions of Marx and communism. ${ }^{5}$ Thus, students first encounter Tocqueville in the larger context of understanding democracy in the West before they read his Author's Introduction to Democracy in America. Students first encounter Marx in the context of understanding communism and postcommunism before they read The Communist Manifesto (parts I, II, and IV). I set aside most of a class period to discuss the question of what Tocqueville and Marx would think of American Idol. ${ }^{6}$

Ideally, we would spend more than 40 to 50 minutes on each of these two seminal authors. But, as anyone that teaches undergraduate introductory courses knows, we are regularly tasked to cover a significant amount of material in a limited amount of time. One of our greatest challenges is to ensure that students can grasp and internalize the material as we whisk through at an occasionally breakneck pace.

I do not assign students specific clips of American Idol to watch, either in or outside of class (although they are certainly free to do so on their own). Although this approach relies on students' familiarity with American Idol, I have not found it to be a limitation. True, different students have different levels of familiarity with Idol's nuances (e.g., they may not know that contestants are often required to sing from a limited selection of songs). But the assignment is not intended to judge students' correct interpretation of American Idol, but rather to see how well they can select passages from Marx and Tocqueville to apply to the show in their analyti- the effects of equality in America. Such disagreements led to energetic debates, in which students called upon specific references from the text to support their positions.

Students who believe that Tocqueville would embrace Idol (perhaps as a fan) point to the French philosopher's emphasis on democracy's role in leveling social differences in rank: "the noble has gone down the social ladder, and the commoner has gone up" (309). They remind the class that Tocqueville argues that democracy, on the whole, is a positive development (even "the work of God"), and that the advance of equality is "universal, it is lasting, it constantly eludes all human interference" (310). These students regularly emphasize that Idol's format substantially alters the balance of power between artist and producer. Because the show holds auditions across the United States, almost anyone has a shot at auditioning before a panel of A-list Hollywood producers, without having to work up the ladder from the bar scene, hoping to be discovered. Once on the show, contestants sing before a live audience of millions on a weekly basis. More important, despite the comments by the panel of judges-particularly the harsh criticism typical of Simon Cowell-contestants' futures are in the hand of common viewers, not experts. In short, students argue that because of Idol, "distinctions of rank are done away with" (311). Democracy, in short, is good, and American Idol is evidence of (musical) democracy in action.

Additionally, students familiar with Putnam's arguments about "social capital" suggest that Tocqueville would approve of Idol precisely because it builds social capital. They point out that Idol brings people together for viewing parties, that students from different social groups engage in conversations about each episode 
(the ubiquitous "water cooler" effect), and that the show encourages active participation through voting. Further, they point to the strong bonds of friendship and camaraderie developed between contestants as evidence of social capital.

Other students, however, think that Tocqueville would be critical of Idol. They point to statements in which the author bemoans the loss of "high" culture brought about by democracy's relentless leveling: "We have destroyed an aristocracy, and we seem inclined to survey its ruins with complacency and accept them" (313). They point to the low quality of many contestants during the preliminary phase, particularly the masses of people with little or no talent clinging to the hope that they, too, can become pop stars. Tocqueville, such students argue, would describe such masses as a "coarse and ignorant multitude" (311). Others cite Tocqueville's admonition that such people have been "abandoned to [their] wild instincts, and [have] grown up like those children who have no parental guidance ... and who are acquainted only with the vices and wretchedness of society" (311). Democracy, in short, may be inevitable, but it comes with a hefty price.

Still others believe that Tocqueville's attitude toward the show might be more ambiguous. Yes, contestants and viewers know that the fate of each season's future pop stars rests in a democratic vote by television audience members. But everyone still really wants to please Simon Cowell (in particular) and the rest of the panel of judges. Such students point to this passage by Tocqueville: "The spell of royalty is broken ... The people have learned to despise all authority, but they still fear it" (312). At the same time, even though contestants frequently claim they want to chart their own path to stardom, they slowly change their clothing, hair, and mannerisms based on the judges' advice. In the end, perhaps Idol has leveled the playing field and given everyone a chance to become a pop star. But they are all slowly becoming the same kind of pop star.

\section{MARX AND AMERICAN IDOL}

Most students react to Marx as I expected: they overwhelmingly argue that Marx (the father of communism and therefore all things "anti-American") would be extremely critical of American Idol. After all, Idol is closely tied to American consumerism and is managed by a group of producers whose sole stated purpose is to find new artists for their production label (19 Management). Interestingly, students are able to put themselves into the role of Karl Marx, using his own words to launch strong criticisms of the Idol franchise. Still, a small minority of students believe that Marx would actually approve of Idol, and they make interesting arguments to support this conclusion.

When students argue for Marx's critical view of American Idol, they point to key passages from The Communist Manifesto. The main source of their critique is that Idol has replaced the traditional mode by which artists become pop singers (e.g., paying one's dues in local clubs, waiting to be discovered). Sure, such a mode of discovery is fraught with the dangers of exploitation, but students argue that Idol's producers have merely replaced one form of exploitation with "naked, shameless, direct, brutal exploitation" (354). Before, musicians honed their skills in the small clubthe "little workshops of the patriarchal master" (357); now they compete on the Idol stage- "the great factory of the industrial capitalist" (357). The gigantic scale of the competition, involving thousands of contestants, also means that the "[m] asses of laborers, crowded into the factory, are organized like soldiers" (357). In par- ticular, students point to the original auditions, in which untalented contestants are publicly berated and mocked on camera for the pleasure of the television audience. This aspect of the audition process also highlights the cutthroat nature of Idol's competition format.

Students also believe that Marx would have criticized the "commoditization" of the show's contestants. They point to such passages as: "These laborers, who must sell themselves piecemeal, are a commodity, like every other article of commerce, and are consequently exposed to all the vicissitudes of competition" (356). Not only are contestants mere commodities (since they try to sell their performance), but over the course of the show, they are heavily pushed to modify their dress, hair, and even mannerisms to become more marketable, as defined by the show's producers and the panel of judges. This pressure means that the "work of the proletarians has lost all individual character ... [becoming] an appendage of the machine" (356-57). Such criticisms equate Idol with a musical sweatshop, with contestants having little freedom to either perform their own original material (they must sing the hits of other, established pop stars) or otherwise go beyond rigid pop conventions.

Other students focus their criticism on the Idol franchise empire instead. They suggest that Marx would see in American Idol merely another example of a capitalist enterprise seeking to monopolize an entire market (in this case, pop music). With more than 40 licensed franchises, including regional competitions on every continent, Marx would see evidence here that the "need for a constantly expanding market for its product chases the bourgeoisie over the whole surface of the globe" (355). Yet some students see this global reach as a potentially positive sign, given that Idol's universal appeal suggests that "[n] ational differences and antagonisms between peoples are daily more and more vanishing" (363). On the one hand, the whole world is becoming homogenized to the same kind of pop culture, but this trend could also diminish the sources of differentness that cause frictions between peoples. If India and Pakistan both have an Idol franchise, can peace be far behind?

A few students offer a more nuanced interpretation. They see in Idol a bourgeois revolution sweeping away the aristocracy of traditional pop stars. When a virtual unknown like Kelly Clarkson can become a double-platinum recording artist, is it still accurate to speak of Michael Jackson as the "King of Pop"? For these students, Idol represents a middle-class revolution that will inevitably set the stage for a future proletarian one. They point to how the Idol revolution demonstrates that the "bourgeoisie cannot exist without constantly revolutionizing the instruments of production, and thereby the relations of production, and with them the whole relations of society" (354-55). Clearly, American Idol is revolutionizing American pop culture in significant ways: the bestselling pop musicians now increasingly come from the ranks of Idol winners and top contestants, which makes the show an attractive way for singers to bypass the club scene entirely (altering "the relations of production") with the hope of being catapulted directly into the limelight. Meanwhile, American Idol has altered our cultural fabric ("the relations of society"). These students argue that Marx predicts that, in time, "the bourgeois itself ... supplies the proletariat with its own elements of political and general education ... it furnishes the proletariat with the weapons for fighting the bourgeoisie" (358). The advice given to contestants (and televised to the audience) during the Hollywood boot camp epi- 
sodes, as well as throughout the competition more generally, imparts important advice to other aspiring musicians in the audience. If Marx were alive today, these students argue, he would suggest that the lessons of American Idol will in time revolutionize the relationship of artists with their audience. Such students invariably point out that the Internet (particularly sites like MySpace and YouTube) allows potential pop stars to appeal directly to their audience, bypassing producers entirely.

\section{CONCLUSION}

Overall, these class discussions have been successful. The addition of a writing exercise strengthened the conversations by allowing students to better prepare for them. But the most remarkable measure of success has been that students come away from Tocqueville and Marx with a deeper understanding of each figure's argument. This outcome is particularly striking with Marx, a figure who many undergraduates dismiss as irrelevant in a post-Cold War world. Yet, most students are able to internalize the theory behind Marx's critique of capitalism and apply it to American Idol. Such students may still leave class strongly disagreeing with Marx, which is fine. But they also leave class with a fuller understanding of what Marx actually argues, which is what truly matters.

Finally, these class discussions are a powerful way to get students to think critically about their own cultural environment. In large part, this occurs because American Idol is "safe." Asking students to deconstruct American political culture can be a painful process. Students are closely tied to their culture and often unwilling to question some of their own assumptions. For undergraduates who have learned little more than praises of American exceptionalism in high school civics or government classes, critiquing American democracy can often be excruciatingly difficult. But a class discussion of American Idol induces them to do just that. As they look to Marx and Tocqueville for insights into a popular television show, they inevitable make connections with their broader political culture.

\section{NOTES}

I thank my students at Dickinson College and Mount St. Mary's University, where this class exercise was first developed. Ialso especially thank David Rehm and MichaelJ. Towle.
1. Unlike Putnam, who is a self-described "neo-Tocquevillian," Robert Reich is not a self-described Marxist. Marx does not even appear in the book's index. Still, it is hard to fathom that a trained economist would be unfamiliar with the general thrust of Marx's argument. Even a superficial glance at Supercapitalism reveals its indebtedness to Marx, even if Reich does not come to Marx's radical conclusions.

2. In defining "popular" films or television shows, I specifically exclude documentaries or similar works, which are also often used by a number of teachers (including myself).

3. Since 2003, American Idol has remained one of the most-watched television shows in history. It has remained in the \#1 spot according to the Nielsen ratings for more than five consecutive seasons, a feat matched only by The Cosby Show and All in the Family. Even with a slight drop in viewership in 2009, the season finale attracted 30 million viewers, placing the episode first in its timeslot.

4. Paula Abdul was replaced by Ellen DeGeneres in season nine.

5. Students read both texts in O'Neil and Rogowski (2006). All page citations for both Marx and Tocqueville refer to this edited volume.

6. An alternative approach, which I will test next semester, is to assign both readings during the same week. This schedule may allow for a more direct dialogue between Marx and Tocqueville.

\section{REFEREN CES}

Beavers, Staci L. 2002. "The West Wing as a Pedagological Tool.” PS: Political Science and Politics 35 : 213-16.

Bernardi, Daniel. 1998. Star Trek and History: Race-ing toward a White Future. New Brunswick: Rutgers University Press.

Byrd, Marquita L. 1998. Multicultural Communication and Popular Culture: Racial and Ethnic Images in Star Trek. New York: McGraw-Hill.

Crawley, Melissa. 2006. Mr. Sorkin Goes to Washington: Shaping the President on Television's The West Wing. Jefferson: McFarland.

O'Connor, John E. 1987. Teaching History with Film and Television. Washington, DC: American Historical Association.

O’Neil, Patrick H., and Ronald Rogowski, eds. 2006. Essential Readings in Comparative Politics. 2nd ed. New York: W. W. Norton.

Parry-Giles, Trevor and Shawn J. Parry-Giles. 2006. The Prime-Time Presidency: The West Wing and U.S. Nationalism. Urbana: University of Illinois Press.

Putnam, Robert. 200o. Bowling Alone: The Collapse and Revival of American Community. New York: Simon \& Schuster.

Reich, Robert. 2007. Supercapitalism: The Transformation of Business, Democracy, and Everyday Life. New York: Knopf.

Rollins, Peter C., and John E. O'Connor. 2003. The West Wing: The American Presidency as Television Drama. Syracuse: Syracuse University Press. 


\section{American Political Science Association}

\section{EDUCATION, PROFESSIONAL, \& DIVERSITY INITIATIVES}

The American Political Science Association (founded in 1903) is a membership association that provides resources for research, networking, and professional development to its 15,000 members in the U.S. and abroad in the political science discipline. The APSA Office of Education, Professional and Minority Initiatives offers resources to students and faculty alike. APSA is dedicated to the promotion of excellence in the areas of education, professional development, and diversity.

Please share the following list of APSA programs with your departments, colleagues, and students and visit www.apsanet.org/education for more information.

\section{Education Programs and Initiatives}

One key component of APSA's mission is to support political science education and to promote high quality teaching and education about politics and government:

- Graduate Student Outreach

- Grants, Funding and Fellowship Resources

- Political Science Education Organized Section

- Committee on Civic Education and Engagement

- Teaching and Learning Conference

\section{Professional Development Programs}

APSA seeks to enhance the professional development of its practitioners by providing academic and non-academic opportunities for members:

- APSA Mentoring Initiative

- APSA Annual Meeting

- Undergraduate/Graduate Student Membership

- eJobs: APSA's online job database

- eJobs Annual Meeting Placement Interview Service

- Career Resources and pamphlets

- Job Candidate Questions to Ask

- Professional networking tools and newsletters

\section{APSA Minority and Diversity Initiatives}

Part of the APSA mission is to enhance diversity in the political science discipline. To that end, APSA provides several programs and resources to assist students from underrepresented groups who are considering an advanced degree in political science.

- APSA Minority Fellows Program (MFP) (seniors or MA students)

- Ralph Bunche Summer Institute (RBSI) (juniors)

- Minority Student Recruitment Project (MSRP)

- APSA Mentoring Initiative

\section{For more information, visit www.apsanet.org or contactepd@apsanet.org.}

